\title{
Goal setting as a means of improved mental health outcomes for materials and mechanical engineering students
}

\section{Dr. Nicole Johnson-Glauch, California Polytechnic State University}

Nicole received her B.S. in Engineering Physics at the Colorado School of Mines ('13) and her PhD in Materials Science and Engineering at the University of Illinois at Urbana-Champaign ('18). She is currently a lecturer in the Materials Engineering Department at California Polytechnic State University in San Luis Obispo. In addition to teaching across the curriculum, she studies mental health in engineering students and engages in outreach with underrepresented groups in STEM.

\section{Dr. Lauren Anne Cooper, California Polytechnic State University, San Luis Obispo}

Lauren Cooper earned her Ph.D. in Mechanical Engineering with a research emphasis in Engineering Education from University of Colorado Boulder. She is currently an Assistant Professor in Mechanical Engineering at California Polytechnic State University in San Luis Obispo. Her research interests include project-based learning, student motivation, human-centered design, and the role of empathy in engineering teaching and learning.

\section{Dr. Trevor Scott Harding, California Polytechnic State University, San Luis Obispo}

Dr. Trevor S. Harding is Professor and Department Chair of Materials Engineering at California Polytechnic State University where he teaches courses in materials selection and polymers. He has presented his research on engineering ethics to several universities and to the American Bar Association. He serves as Associate Editor of the journals Advances in Engineering Education and International Journal of Service Learning in Engineering. He has served as program chair and division chair for several divisions within ASEE. 


\title{
Self-Efficacy and Mental Wellness Goals in Materials Engineering and Mechanical Engineering Students
}

\begin{abstract}
The mental well-being of undergraduate students is a growing concern among engineering programs. A recent study at a large public institution in the West found that $38 \%$ of engineering students who responded to a mental health survey (n 700) screened as high risk of serious mental illness. When broken down by major, $25 \%$ of the materials engineering student respondents were at high risk, and $28 \%$ of the mechanical engineering student respondents were at high risk, compared to $38 \%$ for the overall engineering population. To address this problem, we designed a study to understand the mental wellness goals important to materials engineering and mechanical engineering students. This study sought to answer the following questions: 1) what types of goals, related to mental well-being, are important to materials engineering and mechanical engineering students and 2) does incorporating a mental wellbeing assignment improve students' generalized self-efficacy beliefs? Our results indicate that participants' mental health goals centered around eight areas and focused on aspects of physical health such as sleep and exercise. While we did not observe a statistically significant increase in self-efficacy with the mental health action plan assignment, students with lower initial self-efficacy scores showed bigger increases compared to students with higher initial self-efficacy scores. This result suggests that these types of assignments may preferentially benefit students with low selfefficacy.
\end{abstract}

\section{Background}

There is a growing concern about the mental wellness of undergraduate engineering students. A recent preliminary study at a large public institution on the pacific central coast found that $38 \%$ of engineering students who responded to a mental health survey $(\mathrm{n}>700)$ screened as high risk of serious mental illness, including anxiety, depression, panic disorder, eating disorders, and drug and alcohol abuse [1]. When broken down by major, $25 \%$ of these high-risk respondents were from materials engineering, and $28 \%$ were from mechanical engineering.

Although there are resources on campus to help students with their mental wellbeing, majorspecific courses are where students first learn the norms of their discipline's culture, which could include an unhealthy work-life balance that can lead to increased mental health risks. Those of us who want to address this big-picture problem would benefit from knowing, in more specificity, the types of mental wellness goals students find important, as well as their preferred goal-achievement strategies. Knowing these will help faculty and staff be more pro-active in supporting their students. For example, if a salient mental wellness goal is to reduce general anxiety through strategies related to better time-management, instructors may implement a timemanagement lesson into existing curricula or use policies such as extra credit for submitting completed assignments early. 
We broadly define mental wellness to be a state of wellbeing in which students are generally happy, healthy, and involved and engaged with multiple aspects of their lives. Students are able to deal with the inevitable stresses of life, using positive coping strategies, and are able to find and maintain a sustainable work-life balance. While mental wellness has been extensively studied in populations of different ages and backgrounds[2], studies on mental wellness in undergraduate engineering students are relatively scarce. This study will contribute to the engineering education literature by providing a description of the types of mental wellness goals that are important to materials engineering and mechanical engineering students.

Within research on mental wellness, there appears to be a link between mental wellness and selfefficacy [3]-[9]. Self-efficacy has been conceptualized as a set of beliefs that people have about our own abilities to meet challenges and successfully complete tasks[10]. It is important to study self-efficacy in engineering as it has consistently been found to predict academic performance [11], [12] and career choice [13], [14]. Self-efficacy has been studied as both a task-specific set of beliefs (e.g., academic self-efficacy) [12], [15]-[19] or as a task-general set of beliefs (e.g., generalized self-efficacy) [10], [20]. In this study, we chose to use Sherer et al's generalized selfefficacy scale due to the open-ended nature of the mental health assignment used in the study. Additionally, some researchers suggest that improving generalized self-efficacy will also increase task-specific self-efficacy [10], [21].

According to Sherer et al, generalized self-efficacy is "a general set of [self-efficacy] expectations that the individual carries into new situations" [10]. The authors expected that working on their mental health would involve several new situations for students, which made this generalized self-efficacy scale seem more appropriate for use in the study than taskspecific self-efficacy scales. While self-efficacy has been studied in the context of mental health, it has thus far not been used to study mental health of engineering students to the authors' knowledge.

\section{Research questions}

The purpose of our study is to explore the types of goals related to mental wellness that are important to engineering students and to identify changes in self-efficacy associated with engaging in activities related to improving mental wellness. Based on the above motivation and the gaps in the literature, we designed the study to answer two research questions:

1) What types of goals, related to mental wellbeing, are important to materials engineering and mechanical engineering students?

2) Does incorporating a mental wellbeing assignment improve students' generalized self-efficacy beliefs?

\section{Methods}

\section{Subject characteristics}

Research subjects were recruited from two classes in the Mechanical Engineering and Materials Engineering Departments (ME234: Philosophy of Design, and MATE 232: Materials, Ethics, 
and Society). Out of the 37 students enrolled in ME234, eight students opted to participate in the study. Out of the 42 students enrolled in MATE 232, 35 students opted to participate in the study with 19 completing all parts of the study. Participation in the study was voluntary, and no extra credit was awarded for participation.

Demographic characteristics of the 27 students who participated in the study are shown in Figures 1 and 2. The dominant demographic was white male from middle income families. Most students did not transfer from another institution or community college, and most students were not the first in their families to attend college.

Gender

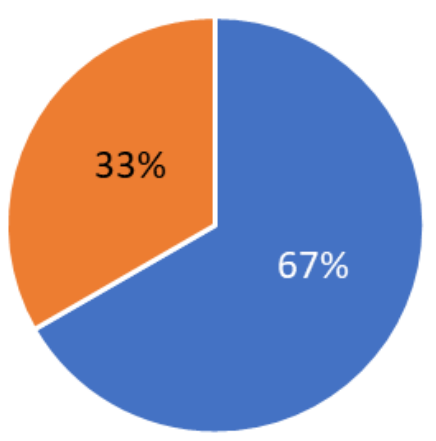

- \% Male $\quad \%$ Female
Ethnicity

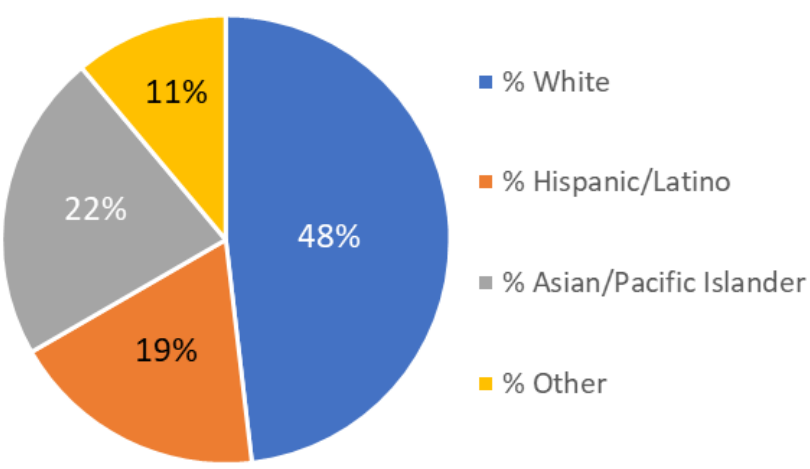

Figure 1: Gender and Ethnicity Demographics of Study Participants 
Transfer Student

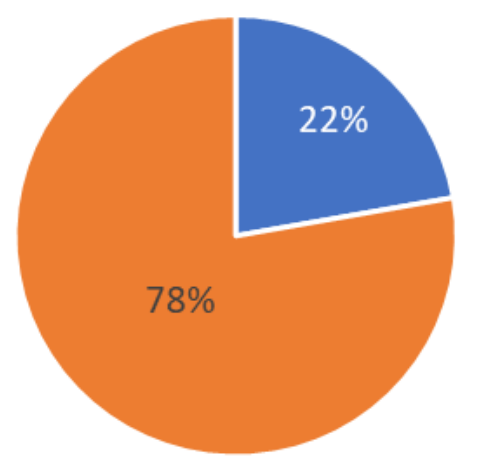

- \% Transer $\quad$ \% Not Transer

\section{First Generation College Student}

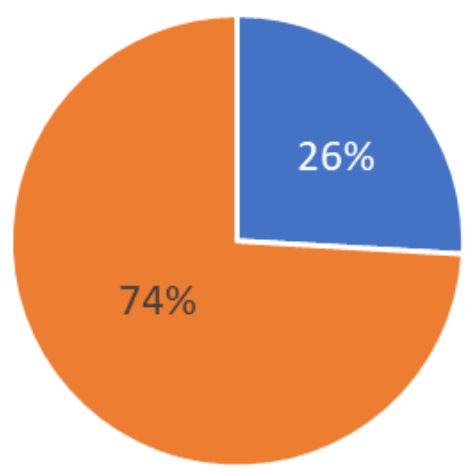

- \% First Gen \% Not First Gen

\section{Income Level}

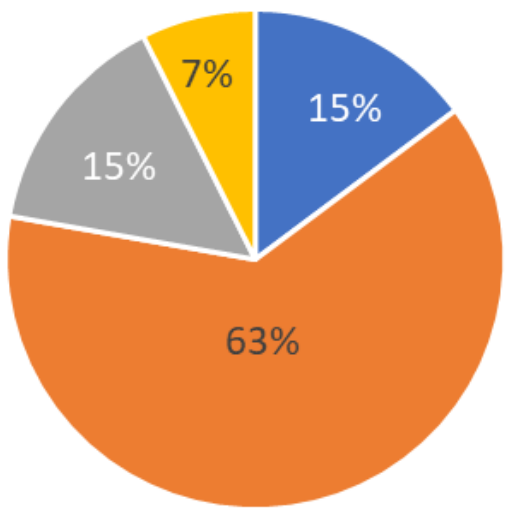

- \% Low Income

- \% Middle Income

- \% High Income

- \% Not sure

Figure 2: Income, Transfer and First-Generation Demographics of Study Participants

\section{Data collection and analysis}

We used a mixed-methods research design, combining quantitative and qualitative methods. Quantitative methods consisted of pre- and post- course surveys to measure changes in students' levels of self-efficacy beliefs. Self-efficacy was measured with a 17-item validated instrument commonly used to measure general self-efficacy [22]. We used the Shapiro-Wilks test to verify the normality of the data before conducting a paired t-test to determine the effect of the action plan assignment on students' self-efficacy. We used a p value of 0.05 as our basis for statistical significance for both tests. In our survey, we also included six demographics questions such as ethnicity, gender, socio-economic status, transfer student status, and employment status. 
Qualitative methods consisted of a content analysis of the students' finalized "Action Plan for Mental Wellness" assignment (see study context below) as well as students' responses to the free-response questions on the post-course survey:

Overall, how successful do you feel you were at working toward your goal? Did you surpass or fall short of your own expectations? Has working toward your goal had a positive impact on any other areas of your life? What have you learned from this goalsetting experience that you might apply in the future?

The overarching goal of the content analysis was to determine the types of mental wellness goals students find important, and to determine some potential connections between students' selfefficacy beliefs and their success at achieving personal goals.

\section{Study context}

All students in both ME234 and MATE 232 completed an ongoing "Action Plan for Mental Wellness" assignment over a period of eight weeks. An action plan is a sequence of steps that must be taken, or activities that must be performed, for a goal to be realized. The action plan assignment has five major elements:

- Overall goal

- Measurable tasks

- Timeline

- Rewards

- Progress log

The assignment prompted students to first select a big-picture goal related to mental wellness that they wanted to work toward. Goals suggested to students included increasing exercise, improving eating habits, getting more regular sleep, joining a club, learning relaxation techniques, etc. Students were allowed to choose any goal for the assignment so long as it related to mental wellness and was realistic to make progress toward during the subsequent eight weeks. Students were free to choose any mental-wellness related goal; we expected students would choose goals related to time management, sleep, exercise, personal time, relationships, etc. However, as stated above, the types of goals students find important is one of the questions this study aims to answer.

Students were then instructed to split up their big-picture goal into several manageable and measurable tasks, then assign deadlines for each task. Lastly, it was recommended (but not required) that students assign a reward to each deadline. A modest purchase, an outing with friends, or extra time doing something the student enjoys are all types of reasonable rewards. Below is a simple instructor-developed action plan that was shown to the students to help them get started. An example of a student-developed action plan is in Appendix A. 
Action Plan to Keep House Clean

1. Big-picture goal: Keep kitchen and bedroom clean.

2. Measureable Tasks: Kitchen-put away all dishes, clean

counters, and floors. Keep fridge clean. Bedroom - make bed every

morning, put things in their designated places, keep floor clean.

3. Timeline: tasks should be completed each day, preferably a

little at time, but with a "deadline" of bedtime.

4. Rewards: Every week goal is met, I can purchase a small

item related to kitchen or bedroom improvement.

5. Progress Log: Journal what I specifically achieved each week.

Figure 3: Instructor-developed Action Plan Example for Students

Once students submitted their Action Plans and received instructor feedback, students began to enact their plan. Along the way, instructors offered students encouraging comments and resources that might be helpful. For example, one student's Action Plan involved stress reduction through playing music, and part of her Action Plan was to find an inexpensive piano. The instructor sent this student several listings of free pianos in the community, and the student was able to procure the piano and fulfill the rest of her plan. In this way, the Action Plans also helped develop and deepen the personal relationships between students and instructors.

\section{Results and discussion}

\section{Research question 1: what types of goals, related to mental wellbeing, are important to materials engineering and mechanical engineering students?}

Upon reviewing the finalized action plans, students' goals fell into one of eight categories: exercise, health, hobby, sleep, time management, grades, self-care, and social. A distribution of the number of action plans per category is shown in Figure 4. The specific goals are listed by category in Table 1. 


\section{Action Plan Themes}

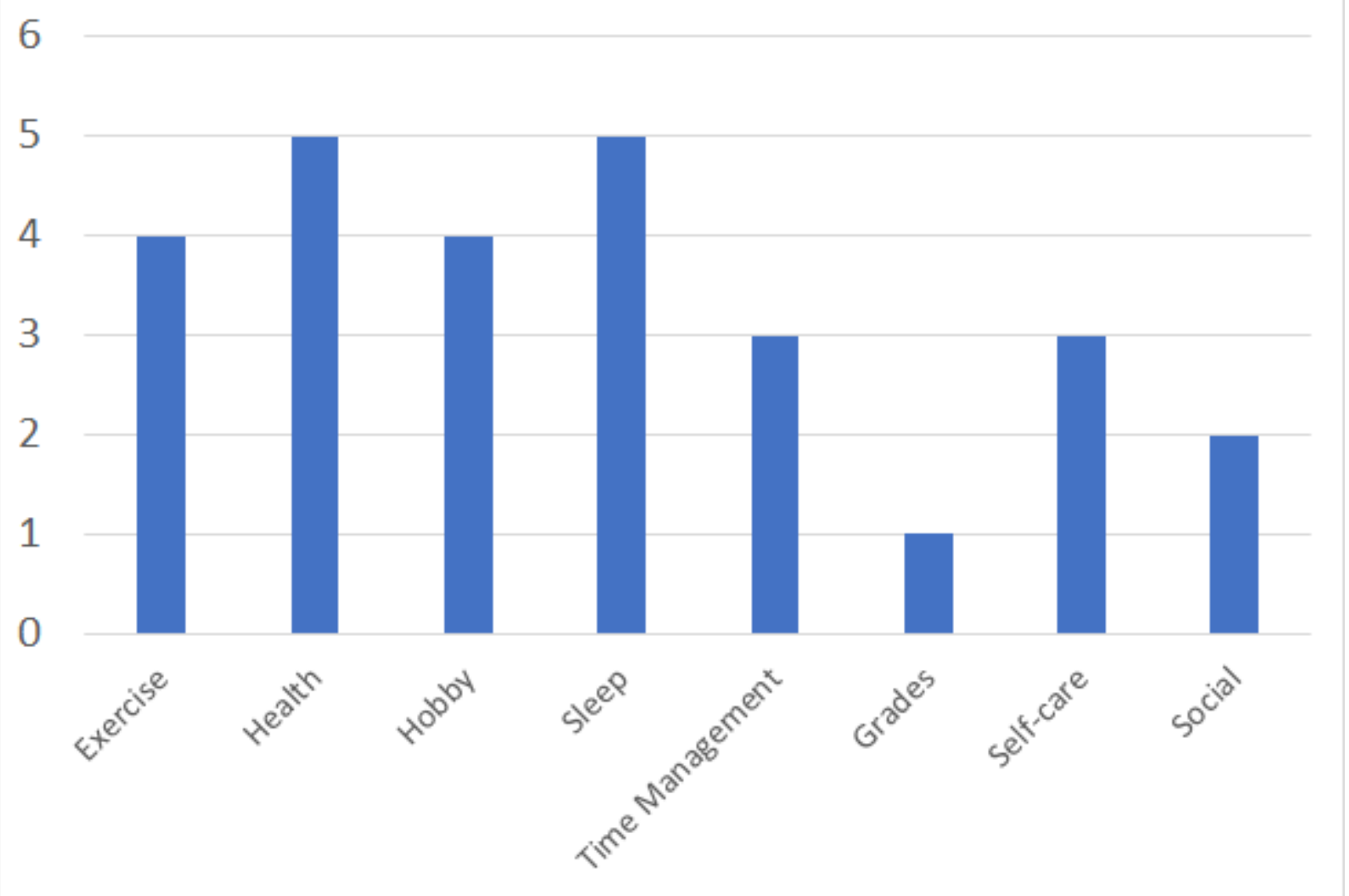

Figure 4: Action Plan Themes by Student 
Table 1: Action Plan Themes and Activities. Action plans created by students who demonstrated large increases in self-efficacy are presented in bold font.

\begin{tabular}{|c|c|c|c|}
\hline Time Management & Grades & Self-care & Social \\
\hline \multirow[t]{4}{*}{$\begin{array}{l}\text { Have better time } \\
\text { management by } \\
\text { creating achievable } \\
\text { schedules }\end{array}$} & Keep my grade & $\begin{array}{l}\text { Journal my thoughts } \\
\text { nightly to keep my } \\
\text { ideas and feelings } \\
\text { straight }\end{array}$ & $\begin{array}{l}\text { Feel happier and less } \\
\text { socially anxious } \\
\text { through more } \\
\text { frequent interaction } \\
\text { with more and new } \\
\text { people }\end{array}$ \\
\hline & & $\begin{array}{l}\text { Work out an effective } \\
\text { means of prioritizing } \\
\text { responsibilities and } \\
\text { self-care }\end{array}$ & $\begin{array}{l}\text { Manage my time more } \\
\text { efficiently so that I } \\
\text { have more time to be } \\
\text { able to form and build } \\
\text { stronger relationships } \\
\text { with as many people as } \\
\text { possible. }\end{array}$ \\
\hline & & Limit negative self-talk & \\
\hline & & Reduce screen time & \\
\hline Exercise & Health & Hobby & Sleep \\
\hline $\begin{array}{l}\text { Establish a consistent } \\
\text { exercise routine }\end{array}$ & $\begin{array}{l}\text { Lose enough weight to } \\
\text { drop down another pant } \\
\text { size or two by the end } \\
\text { of the quarter }\end{array}$ & $\begin{array}{l}\text { Learn the foundations } \\
\text { of how to make a } \\
\text { website and start } \\
\text { developing a prototype }\end{array}$ & $\begin{array}{l}\text { Ease my anxiety by } \\
\text { getting good sleep } \\
\text { each night }\end{array}$ \\
\hline $\begin{array}{l}\text { Attend the gym } 5 \text { days } \\
\text { a week to take a healthy } \\
\text { break and stay fit. }\end{array}$ & $\begin{array}{l}\text { Unclear but looks to be } \\
\text { related to eating healthy }\end{array}$ & $\begin{array}{l}\text { Lower stress by having } \\
\text { time designated to not } \\
\text { do schoolwork }\end{array}$ & $\begin{array}{l}\text { Drink water, REM } \\
\text { sleep, breaks, reduce } \\
\text { blue light }\end{array}$ \\
\hline $\begin{array}{l}\text { Relax Mind and body } \\
\text { using yoga and } \\
\text { stretching }\end{array}$ & $\begin{array}{l}\text { Work on general } \\
\text { health }\end{array}$ & $\begin{array}{l}\text { Lower stress buildup } \\
\text { throughout the week by } \\
\text { actively taking time to } \\
\text { relax throughout the } \\
\text { day and doing } \\
\text { something active/fun } \\
\text { once or twice a week }\end{array}$ & $\begin{array}{l}\text { Improving mood } \\
\text { through getting } \\
\text { adequate sleep most } \\
\text { nights }\end{array}$ \\
\hline \multirow[t]{2}{*}{$\begin{array}{l}\text { Complete at least } 3 \\
\text { physical activities a } \\
\text { week. }\end{array}$} & $\begin{array}{l}\text { Work towards a } \\
\text { healthier lifestyle in } \\
\text { regards to nutrition, } \\
\text { sleep, and exercise }\end{array}$ & Learn a song on guitar & $\begin{array}{l}\text { Get to bed at a regular } \\
\text { time }\end{array}$ \\
\hline & $\begin{array}{l}\text { Create a health } \\
\text { checklist to manage my } \\
\text { anxiety and depression } \\
\text { symptoms }\end{array}$ & & \\
\hline
\end{tabular}

Analysis of free-response survey item revealed some patterns across students. Five of the twentyfive students said they were very successful, accomplishing every aspect of their goal. Five of the twenty-five students said they were unsuccessful in achieving their goal. The remaining 
fifteen students said they were only partially successful in achieving their goal. Students expressed that it was difficult to "stay on track" when they got sick, when midterm season hit, and when other unforeseen circumstances popped up.

"I was doing great but then I got derailed by the break and had a hard time getting back on track. I found that it's best to set a good pattern early and keep it going.

"I didn't feel too successful because my quarter was a lot more difficult than I thought it would be. Finding time to work on something extracurricular was not a frequent option."

However, eighteen of the twenty-five students expressed that working toward their goal had at least some positive impact on other areas of their life:

"Working towards my goal helped my self-confidence and my mental health in general. I have learned how important planning is and using a pre-planned schedule to get things done. I also learned that I benefit from rewarding myself in some way, no matter how small."

"Working towards my goal has also positively impacted just my overall mood and day-today approach to school and my responsibilities by allowing me to manage my stress and let less negativity effect those areas of my life."

"Through this I learned how to...not worry as much and to take life in pieces."

Twelve of the twenty-five students described that they learned the value of setting concrete goals, tracking those goals, and establishing a routine:

"I have learned that quantifying goals helps to achieve them. Abstract goals are often hard to remember to complete. From this experience, I learned that I should track my goals and my progress in the future. This will help me to succeed."

"I learned that putting my goals into writing helped me work towards completing my goal more consistently.

\section{Research question 2: Does incorporating a mental wellbeing assignment improve students' self-efficacy beliefs?}

The pre-course survey data had a mean score of 121.48 and a standard deviation of 5.02. The post-course survey data had a mean of 125.35 and a standard deviation of 5.02. We used a 1-10 Likert scale versus a 1-14 scale that the original instrument used. We tested the validity of the instrument with the new scale using the Cronbach's alpha value, which was 0.91 for our instrument, indicating good instrument validity and consistent with other validation studies [20]. Both the pre- and post-course data met the assumption of normality according to the ShapiroWilk test ( $\mathrm{p}=0.22$ and 0.54 for the pre- and post-course data respectively). Because they met the assumption of normality, we were able to use a two-tailed paired t-test to determine the effect of the action plan assignment. 
The two-tailed paired t-test on the pre- and post-course data showed no statistically significant difference in self-efficacy scores $(\mathrm{p}=0.48)$. While the action plan assignment did not result in a statistically significant change in students' self-efficacy, there appears to be a disproportionate benefit for those with an initial self-efficacy score of approximately half or lower of the total possible score (170 for our ten-point scale). Six of the twenty-seven students had noticeable gains or losses in their self-efficacy score as shown in Table 2. Students with gains or losses in self-efficacy of at least five standard deviations are highlighted green or red respectively. All names listed in Table 2 are gender-neutral pseudonyms. Two of the four students who had large gains in their self-efficacy scores scored low on the pre-course survey (score of 85 or lower) with one student close to our definition of low (88 vs 85 ).

Table 2: Self-efficacy scores from the pre-course survey, post-course survey, and the differences.

\begin{tabular}{|c|c|c|c|}
\hline & \multicolumn{3}{|c|}{ Self-efficacy Survey Score } \\
\hline $\begin{array}{l}\text { Gender-neutral } \\
\text { Pseudonym }\end{array}$ & Pre-course & Post-course & Difference \\
\hline London & 79 & 123 & 44 \\
\hline Kendall & 80 & 87 & 7 \\
\hline Carmen & 81 & 106 & 25 \\
\hline Skyler & 83 & 93 & 10 \\
\hline Jordan & 88 & 121 & 33 \\
\hline Jamie & 92 & 162 & 70 \\
\hline Morgan & 103 & 123 & 20 \\
\hline Angel & 106 & 112 & 6 \\
\hline Riley & 110 & 117 & 7 \\
\hline Quinn & 113 & 92 & -21 \\
\hline Reece & 116 & 128 & 12 \\
\hline Addison & 117 & 126 & 9 \\
\hline Leslie & 118 & 103 & -15 \\
\hline Eden & 123 & 113 & -10 \\
\hline Parker & 128 & 125 & -3 \\
\hline Taylor & 129 & 69 & -60 \\
\hline Amari & 133 & 134 & 1 \\
\hline Hayden & 135 & 141 & 6 \\
\hline Harley & 135 & 159 & 24 \\
\hline Drew & 140 & 146 & 6 \\
\hline Blake & 144 & 140 & -4 \\
\hline Rory & 148 & 148 & 0 \\
\hline Payton & 150 & 157 & 7 \\
\hline Jesse & 151 & 94 & -57 \\
\hline Marley & 155 & 143 & -12 \\
\hline Tatum & 159 & 150 & -9 \\
\hline Blair & 164 & 164 & 0 \\
\hline
\end{tabular}




\section{Conclusion}

Mental health among engineering students is a growing concern among universities. Our study sought to understand what mental health goals are important to mechanical and materials engineering students and to investigate the roll of self-efficacy in their goal setting. Within our study, students' mental health goals centered around eight areas and seemed to focus on aspects of physical health such as sleep and exercise. While we did not observe a statistically significant increase in self-efficacy with the mental health action plan assignment, there appears to be a bigger benefit for those with self-efficacy scores less than half of the total of the instrument. Together, the data suggest that goal-setting activities in the classroom could have a particularly beneficial impact on students with low self-efficacy while not negatively affecting those with moderate or high self-efficacy.

\section{References}

[1] A. Danowitz and K. Beddoes, "Characterizing mental health and wellness in students across engineering disciplines," presented at the Collaborative Network for Engineering and Computing Diversity, 2018, p. 10.

[2] N. Reavley and A. F. Jorm, "Prevention and early intervention to improve mental health in higher education students: a review: Mental health in higher education students," Early Interv. Psychiatry, vol. 4, no. 2, pp. 132-142, Apr. 2010, doi: 10.1111/j.17517893.2010.00167.x.

[3] K. Grøtan, E. R. Sund, and O. Bjerkeset, "Mental Health, Academic Self-Efficacy and Study Progress Among College Students - The SHoT Study, Norway," Front. Psychol., vol. 10, no. 45, pp. 1-11, Jan. 2019, doi: 10.3389/fpsyg.2019.00045.

[4] M. E. D. Caroli and E. Sagone, "Generalized Self-efficacy and Well-being in Adolescents with High vs. Low Scholastic Self-efficacy," Procedia - Soc. Behav. Sci., vol. 141, pp. 867874, Aug. 2014, doi: 10.1016/j.sbspro.2014.05.152.

[5] J. A. D. Datu, "Be happy and believe in your capacity: Establishing link between subjective well-being and self-efficacy among Filipino adolescents," Int. J. Res. Stud. Psychol., vol. 2, no. 2, Aug. 2012, doi: 10.5861/ijrsp.2012.206.

[6] L. A. Milam, G. L. Cohen, C. Mueller, and A. Salles, "The Relationship Between SelfEfficacy and Well-Being Among Surgical Residents," J. Surg. Educ., vol. 76, no. 2, pp. 321328, Mar. 2019, doi: 10.1016/j.jsurg.2018.07.028.

[7] S. Siddiqui, "Impact of Self-Efficacy on Psychological Well-Being among Undergraduate Students," p. 12.

[8] M. Strobel, A. Tumasjan, and M. Spörrle, "Be yourself, believe in yourself, and be happy: Self-efficacy as a mediator between personality factors and subjective well-being: Personality, well-being, and self-efficacy," Scand. J. Psychol., vol. 52, no. 1, pp. 43-48, Feb. 2011, doi: 10.1111/j.1467-9450.2010.00826.x.

[9] Y. Tong and S. Song, "A study on general self-efficacy and subjective well-being of low SES-college students in a Chinese university.," Coll. Stud. J., vol. 38, no. 4, pp. 637-643, 2004. 
[10] M. Sherer, J. Maddux, B. Mercandante, S. Prentice-Dunn, B. Jacobs, and R. Rogers, "The Self-efficacy Scale: Construction and Validation," Psychol. Rep., vol. 51, pp. 663-671, 1982.

[11] P.-H. Hsieh, J. Sullivan, D. Sass, and N. Guerra, "Undergraduate Engineering Students' Beliefs, Coping Strategies, and Academic Performance," vol. 80, no. 2, pp. 196-218, 2012.

[12] C. Vogt, D. Hocevar, and L. Hagedorn, "A Social Cognitive Construct Validation: Determining Women's and Men's Success in Engineering Programs," J. High. Educ., vol. 78, no. 3, pp. 337-36429, 2007.

[13] R. W. Lent, H.-B. Sheu, D. Singley, J. A. Schmidt, L. C. Schmidt, and C. S. Gloster, "Longitudinal relations of self-efficacy to outcome expectations, interests, and major choice goals in engineering students," J. Vocat. Behav., vol. 73, no. 2, pp. 328-335, Oct. 2008, doi: 10.1016/j.jvb.2008.07.005.

[14] A. L. Zeldin, S. L. Britner, and F. Pajares, "A comparative study of the self-efficacy beliefs of successful men and women in mathematics, science, and technology careers," $J$. Res. Sci. Teach., vol. 45, no. 9, pp. 1036-1058, Nov. 2008, doi: 10.1002/tea.20195.

[15] D. Baker, S. Krausse, and S. Y. Purzer, "Developing an instrument to measure tinkering and technical self-efficacy in engineering," in Conference Proceedings, 2008.

[16] M. B. Besterfield-Sacre, L. J. Shuman, and T. Yildirim, "Scale development for engineering modeling self-efficacy.," presented at the ASEE Annual Conference, Louisville, KY, 2010.

[17] A. R. Carberry, H.-S. Lee, and M. W. Ohland, "Measuring Engineering Design SelfEfficacy," J. Eng. Educ., vol. 99, no. 1, pp. 71-79, Jan. 2010, doi: 10.1002/j.21689830.2010.tb01043.x.

[18] T. F. Schubert, F. G. Jacobitz, and E. M. Kim, "Student perceptions and learning of the engineering design process: An assessment at the freshmen level," Res. Eng. Des., vol. 23, no. 3, pp. 177-190, 2012.

[19] J. C. Dunlap, "Problem-based learning and self-efficacy: How a capstone course prepares students for a profession," Educ. Technol. Res. Dev., vol. 53, no. 1, pp. 65-83, Mar. 2005, doi: 10.1007/BF02504858.

[20] S. S. Imam, "Sherer ET AL. GENERAL SELF-EFFICACY SCALE: DIMENSIONALITY, INTERNAL CONSISTENCY, AND TEMPORAL STABILITY," presented at the Redesigning Pedagogy: Culture, Knowledge and Understanding Conference, Singapore, 2007, p. 13.

[21] G. Chen, S. M. Gully, and D. Eden, "Validation of a New General Self-Efficacy Scale," Organ. Res. Methods, vol. 4, no. 1, pp. 62-83, Jan. 2001, doi: 10.1177/109442810141004.

[22] B. Mercandante, S. Prentice-Dunn, B. Jacobs, and R. Rogers, "The Self-Efficacy Scale: Construction and Validation," Psychol. Rep., no. 51, pp. 663-671, 1982. 
Appendix A: example of finalized student action plan

\begin{tabular}{|c|c|c|c|}
\hline & \multicolumn{2}{|c|}{$\begin{array}{l}\text { Goal } \\
\text { Work out an effective means of prioritizing } \\
\text { responsibilities and self-care }\end{array}$} & \\
\hline Task 1 & Task 2 & Task 3 & Task 4 \\
\hline $\begin{array}{l}\text { Maintain a list of } \\
\text { To-do's in order } \\
\text { to keep } \\
\text { responsibilities in } \\
\text { the forefront }\end{array}$ & $\begin{array}{c}\text { Accomplish } \\
\text { responsibilities in } \\
\text { an order that } \\
\text { lowers anxiety, } \\
\text { bite the bullet on } \\
\text { some and don't } \\
\text { over-anticipate } \\
\text { others }\end{array}$ & $\begin{array}{c}\text { Keep track of } \\
\text { what tasks I } \\
\text { consider to be } \\
\text { enjoyable vs what } \\
\text { tasks I do out of } \\
\text { boredom, reflect } \\
\text { on fulfillment }\end{array}$ & $\begin{array}{c}\text { Maintain a } \\
\text { consistent sleep } \\
\text { schedule to force } \\
\text { myself to balance } \\
\text { work vs play, not } \\
\text { work and play vs } \\
\text { sleep. }\end{array}$ \\
\hline$\downarrow$ & $\downarrow$ & $\downarrow$ & $\downarrow$ \\
\hline Resources & Resources & Resources & Resources \\
\hline $\begin{array}{l}\text { Keep physical } \\
\text { track of To-do's, } \\
\text { buy a notepad } \\
\text { that I can always } \\
\text { carry with me to } \\
\text { keep me } \\
\text { accountable }\end{array}$ & $\begin{array}{l}\text { Talking it through } \\
\text { with people who } \\
\text { know me well and } \\
\text { who know what } \\
\text { stresses me out }\end{array}$ & $\begin{array}{l}\text { Like task } 1 \text {, keep } \\
\text { physical } \\
\text { documentation, } \\
\text { write it out to } \\
\text { keep myself } \\
\text { accountable }\end{array}$ & $\begin{array}{l}\text { There's several } \\
\text { sleep related } \\
\text { apps that could } \\
\text { help }\end{array}$ \\
\hline$\checkmark$ & $\checkmark$ & 7 & $\checkmark$ \\
\hline Rewards & Rewards & Rewards & Rewards \\
\hline $\begin{array}{l}\text { Fully crossing off } \\
\text { the list will allow } \\
\text { me to binge some } \\
\text { Watchmen }\end{array}$ & $\begin{array}{c}\text { Buy Fallen Order } \\
\text { Buy Halo } \\
\text { Buy Modern } \\
\text { Warfare }\end{array}$ & $\begin{array}{l}\text { Engage more in } \\
\text { the activities I } \\
\text { enjoy now that I } \\
\text { have } \\
\text { documentation of } \\
\text { what is more } \\
\text { "fulfilling" }\end{array}$ & $\begin{array}{l}\text { Task is self- } \\
\text { rewarding, }\end{array}$ \\
\hline
\end{tabular}

